\title{
Landslide risk analysis: a multi-disciplinary methodological approach
}

\author{
S. Sterlacchini ${ }^{1}$, S. Frigerio ${ }^{1,2}$, P. Giacomelli ${ }^{3}$, and M. Brambilla ${ }^{3}$ \\ ${ }^{1}$ Institute for the Dynamic of Environmental Processes, National Research Council (CNR-IDPA), Piazza della Scienza 1, \\ 20126 Milan, Italy \\ ${ }^{2}$ Department of Environmental Sciences, University of Milan-Bicocca, Piazza della Scienza 1, 20126 Milan, Italy \\ ${ }^{3}$ Department of Agricultural, Agro-Food And Environmental Economics and Policy, University of Milan, Via Celoria 2, \\ 20133 Milan, Italy
}

Received: 5 April 2007 - Revised: 23 October 2007 - Accepted: 25 October 2007 - Published: 13 November 2007

\begin{abstract}
This study describes an analysis carried out within the European community project "ALARM" (Assessment of Landslide Risk and Mitigation in Mountain Areas, 2004) on landslide risk assessment in the municipality of Corvara in Badia, Italy. This mountainous area, located in the central Dolomites (Italian Alps), poses a significant landslide hazard to several man-made and natural objects. Three parameters for determining risk were analysed as an aid to preparedness and mitigation planning: event occurrence probability, elements at risk, and the vulnerability of these elements. Initially, a landslide hazard scenario was defined; this step was followed by the identification of the potential vulnerable elements, by the estimation of the expected physical effects, due to the occurrence of a damaging phenomenon, and by the analysis of social and economic features of the area. Finally, a potential risk scenario was defined, where the relationships between the event, its physical effects, and its economic consequences were investigated. People and public administrators with training and experience in local landsliding and slope processes were involved in each step of the analysis.

A "cause-effect" correlation was applied, derived from the "dose-response" equation initially used in the biological sciences and then adapted by economists for the assessment of environmental risks. The relationship was analysed from a physical point of view and the cause (the natural event) was correlated to the physical effects, i.e. the aesthetic, functional, and structural damage. An economic evaluation of direct and indirect damage was carried out considering the assets in the affected area (i.e., tourist flows, goods, transport and the effect on other social and economic activities). This study shows the importance of indirect damage, which is as significant as direct damage. The total amount of direct damage was estimated in $8913000 €$; on the contrary, indirect
\end{abstract}

Correspondence to: S. Sterlacchini

(simone.sterlacchini@unimib.it) damage ranged considerably from 2840000 to $9350000 €$, depending on the selected temporal scenario and the expected closing time of the potentially affected structures.

The multi-disciplinary approach discussed in this study may assist local decision makers in determining the nature and magnitude of the expected losses due to a dangerous event, which can be anticipated in a given study area, during a specified time period. Besides, a preventive knowledge of the prospective physical effects and economic consequences may help local decision makers to choose the best prevention and mitigation options and to decide how to allocate resources properly, so that potential benefits are maximised at an acceptable cost.

\section{Introduction}

Landslides cause enormous casualties and severe economic losses in mountainous regions worldwide (Schuster, 1996). Preventing or reducing mass movements always involves systematic and rigorous processes to stabilize or "manage" slopes (Fell and Hartford, 1997). Since this is seldom sufficiently recognized (Guzzetti, 2000), new and more effective methodologies need to be developed to increase the understanding of landslide risk and to enable rational decisions to be made on the allocation of funds for landslide risk management.

This study is framed within "ALARM" (Assessment of Landslide Risk and Mitigation in Mountain Areas, 2004), a European Community project that aims to improve existing tools and methods for estimating landslide risk in inhabited areas, and to test their applicability with institutional users and the general public. Several local municipalities were directly involved in the project as potential final users. Corvara in Badia (Autonomous Province of Bolzano, Italy) was chosen as a representative mountain testsite (Figs. 1a, 1b). Within this area, the estimate of the

Published by Copernicus Publications on behalf of the European Geosciences Union. 


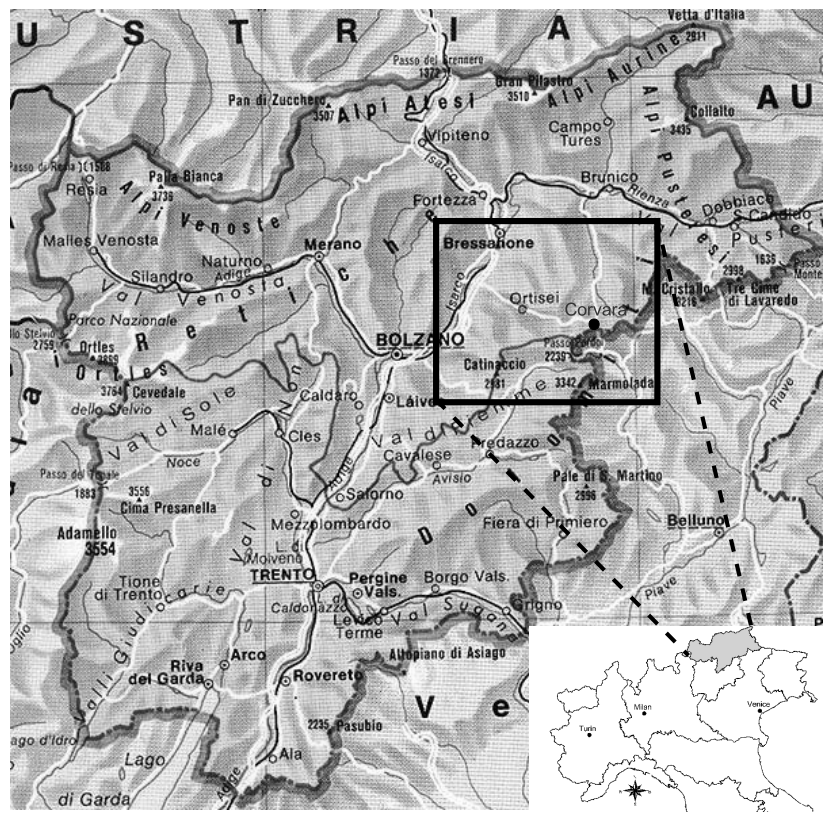

Fig. 1a. Geographical location of the study area (Cartographic website of Italian Environmental Ministry www.pcn.minambiente.it).

prospective physical effects and economic consequences due to a landsliding event was of interest for several potential local end users, such as:

- Public administrators responsible for facilities planning and management;

- Economic planners;

- Managers owning or dealing with buildings or other vulnerable facilities and the insurance companies which guarantee those facilities;

- Lawmakers drafting building regulations or codes of practise for construction, whose task is to ensure that adequate protection is provided at minimum cost;

- People responsible for civil protections, relief and emergency services, whose job is to prepare contingency plans.

The significance of various losses may depend on the time interval considered: in the short term, casualties, homelessness and damage to buildings, infrastructure and equipment may be the primary concern. In the long term, economic loss and social disruption may be of greater importance.

Mitigation measures for future landslide events are becoming increasingly common in municipal planning development, especially where there have been disasters in the past. Preparedness planning focuses on contingency measures during an emergency whereas mitigation planning involves long term control of land use, building quality and

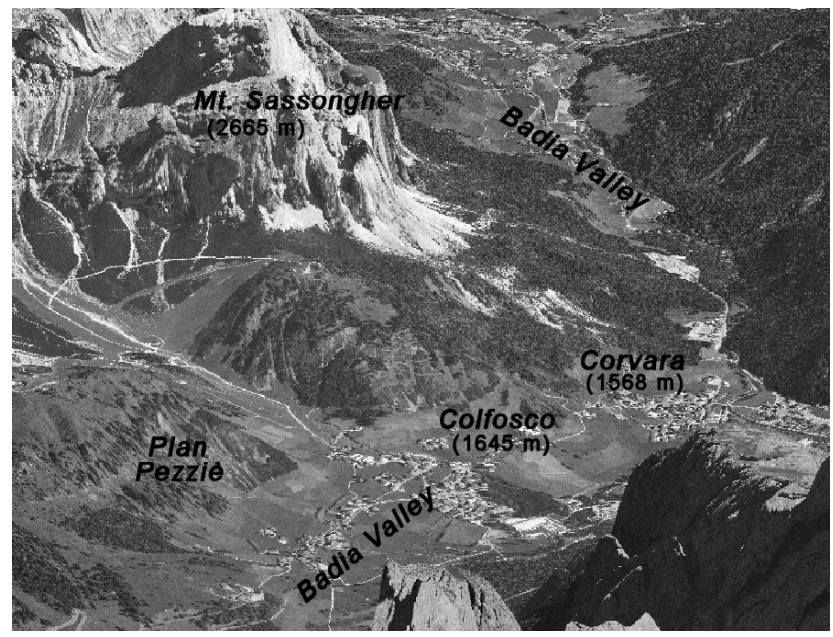

Fig. 1b. 3-D representation of the study area (royalties on Digital Elevation Model and Digital Orthophoto: Autonomous Province of Bolzano-Autonome Provinz Bozen-Sudtirol).

other measures to reduce the impact of a dangerous event. A preventive risk analysis is fundamental for these planning processes. In achieving these aims, the degree of risk, deriving from the expected magnitude of an event and its probable consequences, should be mapped and evaluated as quantitatively as possible.

\section{Landslide risk analysis: state-of-the-art}

An entire risk assessment procedure comprises three essential components (Fig. 2): risk analysis, risk evaluation and risk management (Bell and Glade, 2004a). Risk analysis aims to estimate and display "what could happen" in terms of physical effects and socio-economic consequences in a given environmental setting; risk evaluation is intended to identify risk perception and acceptance of the involved people; risk management combines the results of risk analysis and risk evaluation to find the "best" solution.

Following the definitions developed by the Office of the United Nations Disaster Relief Coordinator (UNDRO, 1979) and the Australian Geomechanics Society (AGS, SubCommittee on Landslide Risk Management, 2000), a quantitative risk analysis, based on the frequency analysis and the probable consequences, may be calculated using the following parameters:

1. Spatial and temporal occurrence probability of a dangerous event;

2. Spatial and temporal impact probability of the event;

3. Value or net present value of the elements at risk;

4. Vulnerability of the elements at risk. 


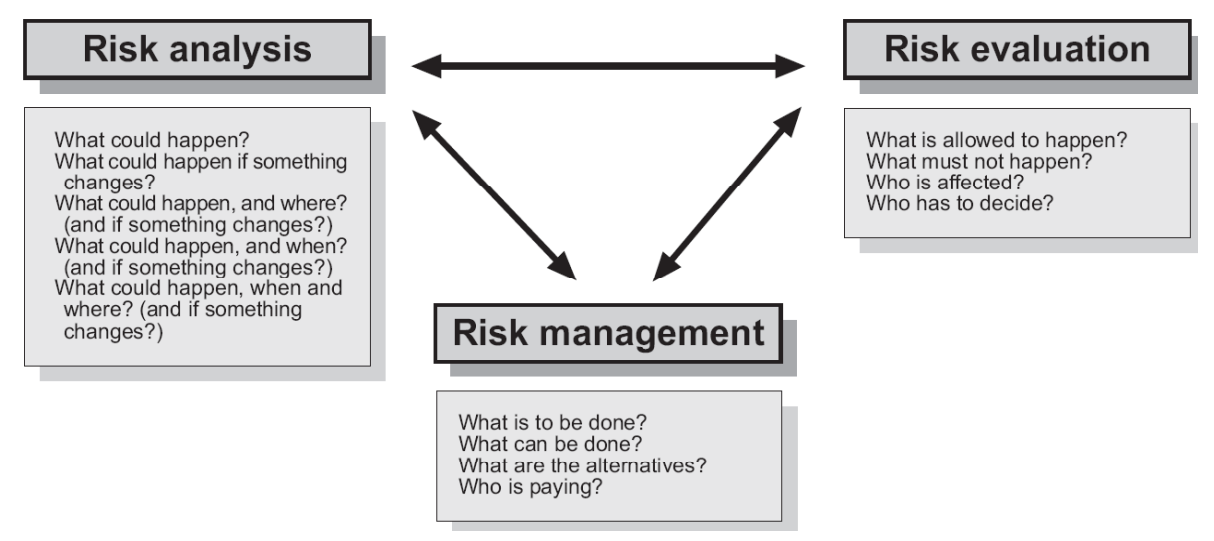

Fig. 2. The holistic concept of risk assessment (Bell and Glade, 2004a).

Many authors have stressed the gap between the theoretical definition of risk and its practical assessment (Carrara et al., 1991; Carrara et al., 1992, 1995; DMTP, 1994; Fell, 1994; Wu et al., 1996; Leroi, 1996; Leone et al., 1996; IUGS, 1997; AGS, 2000; Michael-Leiba et al., 2000; Cardinali et al., 2002; Liu et al., 2002; Bonnard, 2004; Hollenstein, 2005). Difficulties arise in the definition of the parameters mentioned above, which are characterised by several factors that need to be evaluated. Besides, it is important to highlight some aspects:

1. Event occurrence/impact probability is an intrinsically complex parameter (AGS, 2000);

2. Standardised procedures for hazard assessment are still lacking (Carrara et al., 1995);

3. Appropriate data is often difficult to acquire (Carrara et al., 1995);

4. Vulnerability assessment is a somewhat subjective procedure, largely based on historical records (Dai et al., 2002) and expert judgements.

The topics mentioned above help to understand the real value of expert knowledge and professional judgments that are nearly always deeply involved in risk assessment. Each mathematical model used to represent complex natural mechanisms is often integrated with guidelines intended to synthesize human behaviour, choices and actions (Barneich et al., 1996; Ashby, 2002).

Different methods were developed and are nowadays commonly used to estimate the potential physical effects and the economic consequences due to a dangerous event (DMTP, 1994), including:

1. Scenario Mapping, where potential losses (the number of people killed and injured and the damage to buildings and infrastructure) are estimated within pre-defined hazard and vulnerability scenarios. This method is often applied to evaluate the resources needed in case of an emergency.

2. Potential Loss Studies, where the effects of the expected occurrence are mapped, and the locations of communities likely to suffer heavy losses are shown. The "communities most at risk", should be prioritised for loss-reduction programs and strategies, and will need more aid or rescue assistance in case of a major disaster.

3. Annualised Risk Mapping, where the probability of each damaging event over a period of time is combined with the consequences of that event to generate prospective losses within that time. Summing up the losses for all occurrences gives the total losses expected for the period.

Generally, several types of losses can be considered, and this is a topic of increasing discussion. In landslide risk analysis, risk can be quantified in terms of loss of life and it is generally accepted that saving life is the highest priority of disaster mitigation and preparedness programmes. However, many other consequences may be considered: the most common is economic cost. Cost is a widely accepted parameter because many types of loss can be converted into economic cost; it is a currency for considering a wide range of effects. Physical effects evaluated in terms of economic cost are known as tangible losses and can be classified into direct and indirect. However there are many other consequences, which are equally or more important, even if they cannot be converted into a monetary equivalent, and these are referred to as intangible losses: social and psychological consequences on the community resulting from disasters. The occurrence of a calamity may generate changes in human behaviour and actions: people may avoid affected areas on the basis of internal rules that judge the events to be more frequent and dramatic than they actually are (Starmer, 1996). Moreover, the same 


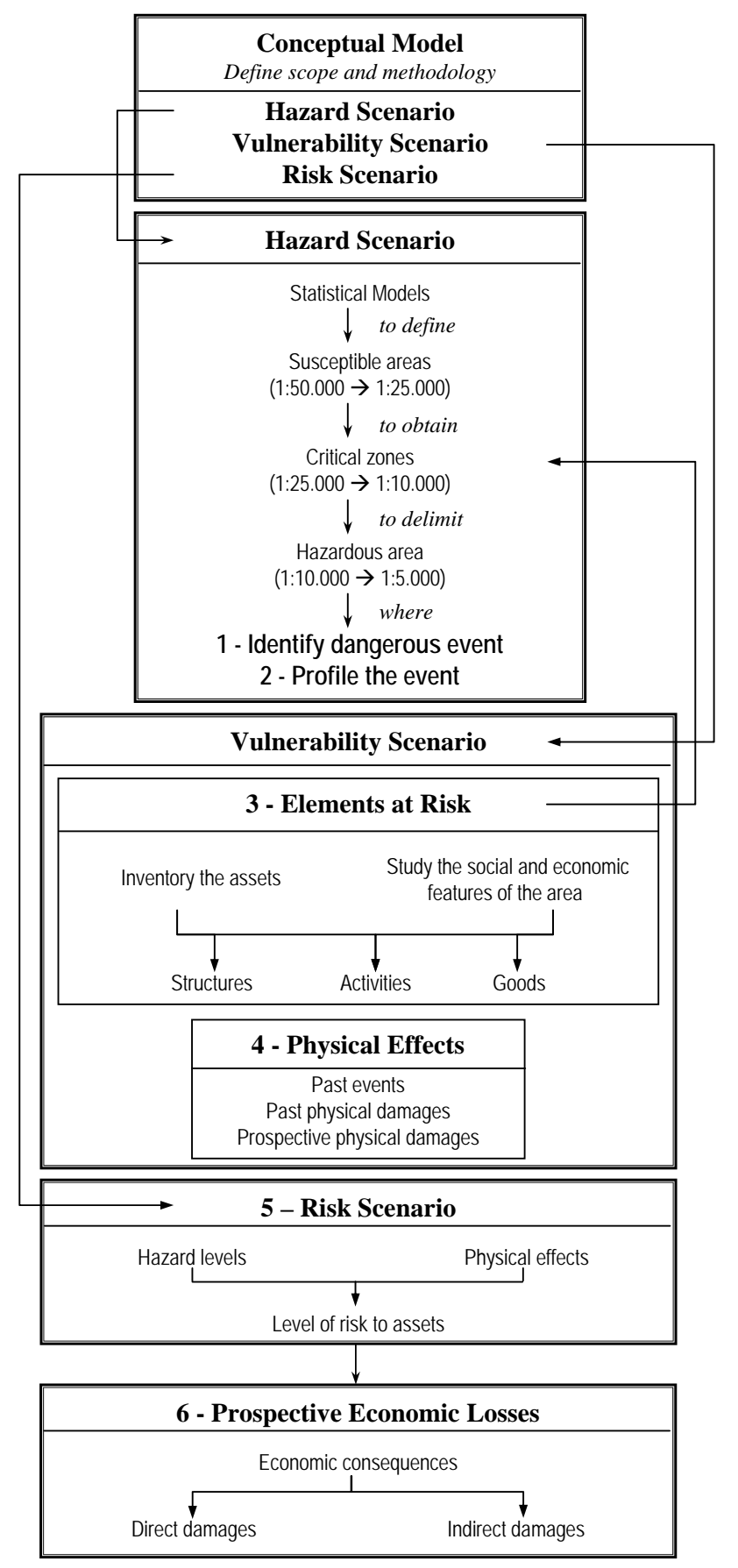

Fig. 3. Scheme of the procedure described in the text. Numbers (from 1 to 6 ) refer to the six-step process explained in paragraph 3.

risk may be perceived differently by individuals and groups. The differences between tangible and intangible losses make their aggregation into a single indicator of disaster impact impossible.

Direct losses can be considered as the "most visible" economic consequences; they may be quantified in terms of cost of recovering and/or restoring the original conditions (for aesthetic and/or functional damage) or in terms of cost of partial or complete reconstruction (for structural damage). Indirect losses are generally related to the loss of revenue, increases in unemployment, and other economic aspects related to the interruption or the reduction of economic activity. These economic considerations may affect the elements directly involved and all the elements that use the destroyed structure for their economic activities. These issues can be explained considering, for example, the partial destruction of a road: this situation generates indirect losses for those elements which use that specific road for their economic activities, even if they are not directly involved in the event. For this reason, the economic analysis has to be related to elements affected both directly and indirectly. To do that, the social and economic context has to be characterized (Blöchl and Braun, 2005): the results of economic and social analysis may be considered as the key to estimating prospective losses (Kienholz, 1994) and to reducing private and public losses, carrying out the best prevention and mitigation options. Evaluating prospective consequences requires "reading" potential damage from a physical, social and economic point of view (Giacomelli, 2005). It is important to predict how the territory might "react" after the impact, considering the physical and environmental features and human behaviour.

\section{A multi-disciplinary methodological approach}

Considering the aim of this study, the extent of the study area and data availability, we carried out only the risk analysis on a local scale (1:5000). A multi-disciplinary approach was defined and applied based on a "cause-effect" correlation, on the "scenario mapping" method, and on rules and assumptions derived from social and environmental economics.

The "cause-effect" correlation is a quantitative relationship derived from the "dose-response" equation frequently used in the biological sciences (Purchase, 2000) for investigating the relationship between a safe dose and the likely harmful effects that may occur if that dose is exceeded. Biological sciences deal with risk as the characterization of the potential adverse effects of human exposure to environmental sources of danger. Economists have adapted this correlation and applied it to the economic assessment of environmental risks (Pearce, 1998; Starmer, 1998; Polelli, 2000).

In this study, the relationship was analysed from a physical point of view, correlating the cause to the prospective physical effects. The "cause" refers to the potentially destructive natural event (with its physical and geometric characteristics), while the physical effects are the aesthetic, functional, and structural damage suffered by the exposed elements (Cardinali et al., 2002) .

In our approach, the prospective physical effects due to the impact of a damaging event correspond to vulnerability 


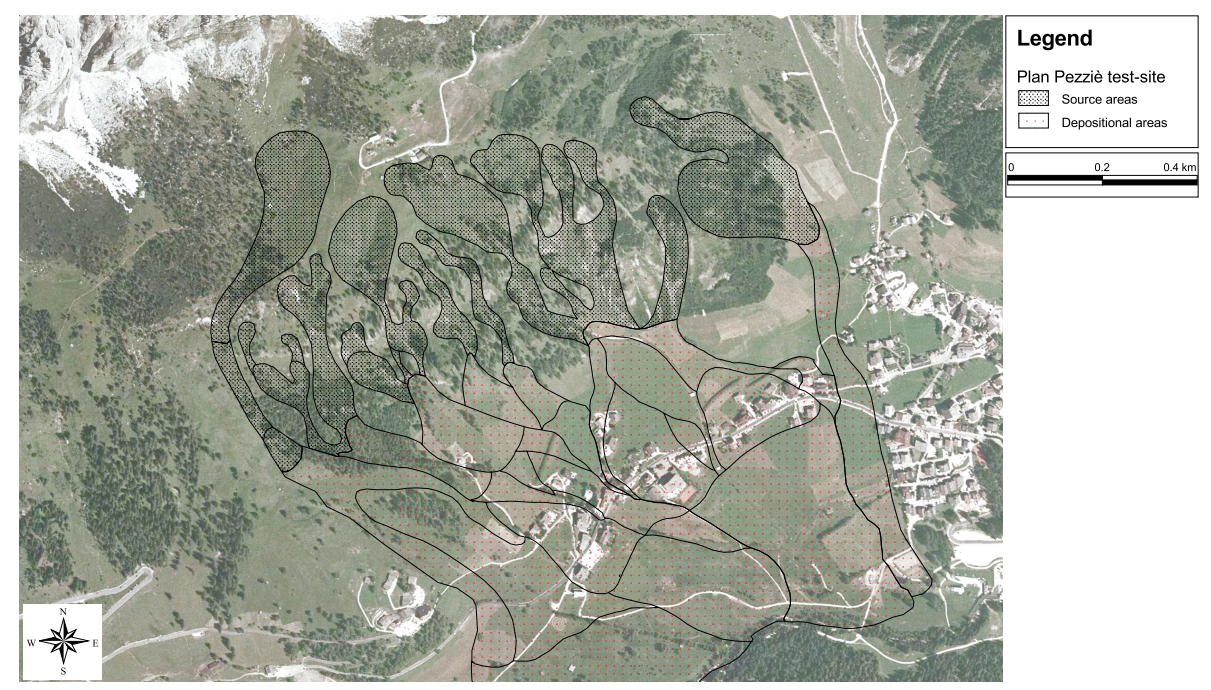

Fig. 4. Plan Pezziè test-site. Source and depositional areas of earth-debris flows are represented. Debris cones are mapped as indicators of high landsliding activity over long periods (royalties on Digital Orthophoto: Autonomous Province of Bolzano-Autonome Provinz BozenSudtirol).

while the prospective social and economic consequences correspond to "consequences", as described in AGS (2000), Glade (2003), and Bell and Glade (2004b).

In this study (Fig. 3), the landslide risk analysis was based on a six-step process (partially modified after Kienholz, 1994; FEMA, 2001):

1. Identify a landslide event which could affect the municipality and its community;

2. Profile the potentially destructive event;

3. Inventory the assets and study the social and economic features of the area;

4. Estimate the physical effects due to the impact;

5. Define an indicative risk scenario;

6. Estimate the prospective social and economic consequences.

People and public administrators with training and experience in local landsliding and slope processes were involved in each step of the analysis to reduce an under/over estimation of the outcomes.

In the first step, a landslide hazard scenario was defined to map and characterise areas prone to slope failures. The entire municipality of Corvara in Badia was classified into homogeneous zones or domains, according to their degree of actual or potential landslide proneness. That was performed by analysing existing susceptibility maps, available in the ALARM project database, and achieved by the application of a statistical methodology (Weights of Evidence modeling technique, Bonham-Carter et al., 1988; Agterberg et al., 1989).

The resulting map was used to identify "critical zones": areas classified as highly susceptible with the presence of vulnerable elements. Among "critical zones", Plan Pezziè area was chosen as a test-site; it is affected by dormant low thickness earth-debris flows with source areas of $248428 \mathrm{~m}^{2}$ and depositional areas of $1278927 \mathrm{~m}^{2}$. The large number of debris cones mapped in the area was a clear indicator of an important gravitational activity over long periods (Fig. 4).

The analysis of available data led to the subdivision of the entire Plan Pezziè area into three zones: the westernmost, the central, and the easternmost sector. The geomorphological setting, the landsliding history, and the spatial distribution of past damage and disruption suggested the central sector as the most hazardous and subject to significant prospective physical effects and social and economic consequences (Plan Pezziè scenario). For this reason, it was analysed in more detail in this study. The central sector has a source area of about $107496 \mathrm{~m}^{2}$ and a very large depositional area of about $618349 \mathrm{~m}^{2}$.

In this step, we identified and described a possible landslide event that could occur within the scenario, whose magnitude and return period were inferred by analysing available data related to the landsliding history of the study area and its neighbourhood. This analysis took into account morphologic and climatic conditions, landslide types, materials involved, volumes, velocities, degrees of activity, and return periods. We did not choose for this study the largest or the most damaging landslides faced by the area and its community, since they relate to past climatic conditions, or are characterised by very low probabilities of occurrence.

A critical review of historical records (Table 1) together 
Table 1. Historical records on landslide events and damage related to the study area and its neighbourhood (up to $25 \mathrm{~km}$ far from study area). Records marked by asterisks are related to events occurred within the study area. Data source: AVI catalogue (Italian Vulnerable Areas) and Local and National chronicles from SICI dataset (Hydrogeological Disaster Information System, available at http://sici.irpi.cnr.it/index. htm); Technical Reports from event documentation of Autonomous Province of Bolzano. (http://www.provinz.bz.it/opere\%2Didrauliche/ attivita1_i.htm).

\begin{tabular}{|c|c|c|c|c|c|}
\hline Source & Event type & $\begin{array}{l}\text { Date } \\
\text { of event }\end{array}$ & Municipality & Location & Damage \\
\hline AVI catalogue & Debris flow & 19 Jun 1821 & Badia & Larzonei & $\begin{array}{l}\text { Dam of Gader river. The } \\
\text { collapse of the dam (for fast } \\
\text { snow melting) destroyed a } \\
\text { lot of buildings in the area }\end{array}$ \\
\hline AVI catalogue & $\begin{array}{l}\text { Earth-debris } \\
\text { flow }\end{array}$ & 24 Mar 1951 & $\begin{array}{l}\text { Santa Cristina Val } \\
\text { Gardena }\end{array}$ & $\begin{array}{l}\text { Santa Cristina } \\
\text { Val Gardena }\end{array}$ & $\begin{array}{l}\text { Damage to bridges and } \\
\text { buildings }\end{array}$ \\
\hline AVI catalogue & Debris flow & 4 Jun 1962 & Badia & Badia & Damage to local roads \\
\hline $\begin{array}{l}\text { Technical } \\
\text { report }(*)\end{array}$ & $\begin{array}{l}\text { Earth-debris } \\
\text { flow }\end{array}$ & Nov 1966 & Corvara in Badia & Col Alto & Minor damage \\
\hline AVI catalogue & $\begin{array}{l}\text { Earth-debris } \\
\text { flow }\end{array}$ & 4 Nov 1966 & $\begin{array}{l}\text { San Martino in } \\
\text { Badia }\end{array}$ & Piccolino Val Badia & $\begin{array}{l}\text { Damage to local roads. } \\
\text { Minor damage to national } \\
\text { road }\end{array}$ \\
\hline AVI catalogue & Debris flow & 3 Aug 1972 & Ponte Gardena & Ponte Gardena & Minor damage \\
\hline $\begin{array}{l}\text { AVI catalogue } \\
(*)\end{array}$ & Debris flow & 13 Nov 1975 & Corvara in Badia & Pralongià & Minor damage \\
\hline AVI catalogue & Debris flow & Oct 1976 & Ponte Gardena & Pontives & Minor damage to roads \\
\hline AVI catalogue & $\begin{array}{l}\text { Earth-debris } \\
\text { flow }\end{array}$ & 31 Jul 1977 & $\begin{array}{l}\text { San Martino in } \\
\text { Badia }\end{array}$ & $\begin{array}{l}\text { Piccolino Val } \\
\text { Badia }\end{array}$ & Damage to buildings \\
\hline $\begin{array}{l}\text { AVI catalogue } \\
(*)\end{array}$ & Debris flow & 23 Jul 1978 & Corvara in Badia & Colfosco & $\begin{array}{l}\text { One person killed and } 200 \\
\text { homelessness }\end{array}$ \\
\hline AVI catalogue & Debris flow & 9 Aug 1979 & Laion & $\begin{array}{l}\text { Chiusa-Ponte } \\
\text { Gardena }\end{array}$ & $\begin{array}{l}\text { Minor damage to national } \\
\text { road. Functional damage to } \\
\text { railway }\end{array}$ \\
\hline AVI catalogue & Debris flow & 19 Jul 1981 & Ponte Gardena & Ponte Gardena & Minor damage \\
\hline AVI catalogue & Debris flow & 2 Sep 1982 & $\begin{array}{l}\text { San Lorenzo di } \\
\text { Sebato }\end{array}$ & Sares-Longega & $\begin{array}{l}\text { Minor damage to national } \\
\text { road }\end{array}$ \\
\hline National chronicle & Debris flow & 28 Jun 1997 & Marebbe & Longega & $\begin{array}{l}\text { Functional damage to local } \\
\text { road }\end{array}$ \\
\hline $\begin{array}{l}\text { National/Local chronicle } \\
\text { AVI catalogue }\end{array}$ & $\begin{array}{l}\text { Debris flow } \\
\text { Earth-debris } \\
\text { flow }\end{array}$ & $\begin{array}{l}28 \text { Jul } 1997 \\
7 \text { Aug } 1997\end{array}$ & $\begin{array}{l}\text { Funes } \\
\text { Selva di Val } \\
\text { Gardena }\end{array}$ & $\begin{array}{l}\text { Albes } \\
\text { Selva di Val } \\
\text { Gardena }\end{array}$ & $\begin{array}{l}\text { Functional damage } \\
\text { to national road SS12 } \\
\text { Functional damage to local } \\
\text { road }\end{array}$ \\
\hline Local chronicle & $\begin{array}{l}\text { Debris } \\
\text { flow/rock falls }\end{array}$ & 29 Apr 1998 & $\begin{array}{l}\text { Selva di Val } \\
\text { Gardena }\end{array}$ & Dantercepies & $\begin{array}{l}\text { Damage to houses and cars. } \\
30 \text { people evacuated } \\
\text { (instability was expected to occur) }\end{array}$ \\
\hline Local chronicle & Debris flow & 12 Jun 1998 & $\begin{array}{l}\text { Selva di Val } \\
\text { Gardena }\end{array}$ & $\begin{array}{l}\text { Colma-Ponte } \\
\text { Gardena }\end{array}$ & $\begin{array}{l}\text { Damage to buildings. } \\
\text { Functional damage to } \\
\text { national road SS12 }\end{array}$ \\
\hline Local chronicle & $\begin{array}{l}\text { Earth-debris } \\
\text { flow }\end{array}$ & 26 Jul 1998 & Marebbe & $\begin{array}{l}\text { San Vigilio di } \\
\text { Marebbe }\end{array}$ & $\begin{array}{l}\text { Functional damage to local } \\
\text { road }\end{array}$ \\
\hline AVI catalogue & Debris flow & 15 Aug 1998 & $\begin{array}{l}\text { Selva di Val } \\
\text { Gardena }\end{array}$ & Miramonti & $\begin{array}{l}\text { Functional damage } \\
\text { to SS243 }\end{array}$ \\
\hline Local chronicle & Debris flow & 7 Oct 1998 & Badia & Pedraces & $\begin{array}{l}\text { Functional damage to } \\
\text { national road SS244 }\end{array}$ \\
\hline Local chronicle & $\begin{array}{l}\text { Earth-debris } \\
\text { flow }\end{array}$ & 7 Oct 1998 & $\begin{array}{l}\text { San Lorenzo } \\
\text { di Sebato }\end{array}$ & $\begin{array}{l}\text { Montana- } \\
\text { Longega }\end{array}$ & $\begin{array}{l}\text { Partial functional damage to } \\
\text { local road, alternate } \\
\text { one-way }\end{array}$ \\
\hline $\begin{array}{l}\text { Local } \\
\text { chronicle }\end{array}$ & Debris flow & 8 Oct 1998 & Badia & $\begin{array}{l}\text { La Villa- } \\
\text { S.Cassiano }\end{array}$ & $\begin{array}{l}\text { Functional damage to local } \\
\text { road }\end{array}$ \\
\hline Local chronicle & $\begin{array}{l}\text { Earth-debris } \\
\text { flow }\end{array}$ & 8 Oct 1998 & $\begin{array}{l}\text { San Martino in } \\
\text { Badia }\end{array}$ & $\begin{array}{l}\text { Pederoa- } \\
\text { Piccolino }\end{array}$ & $\begin{array}{l}\text { Partial functional damage to } \\
\text { local road, alternate one- } \\
\text { way }\end{array}$ \\
\hline Local chronicle & $\begin{array}{l}\text { Earth-debris } \\
\text { flow }\end{array}$ & 7 Nov 2000 & $\begin{array}{l}\text { Selva di Val } \\
\text { Gardena }\end{array}$ & $\begin{array}{l}\text { Selva di Val } \\
\text { Gardena }\end{array}$ & $\begin{array}{l}\text { Functional damage to } \\
\text { national road SS243 }\end{array}$ \\
\hline Technical report & $\begin{array}{l}\text { Earth-debris } \\
\text { flow }\end{array}$ & $\begin{array}{l}\text { recurrent } \\
\text { and } \\
\text { seasonal }\end{array}$ & $\begin{array}{l}\text { Selva di Val } \\
\text { Gardena }\end{array}$ & Passo Gardena & $\begin{array}{l}\text { Frequent and continuous } \\
\text { damage to SS243 }\end{array}$ \\
\hline
\end{tabular}


with local knowledge and expert opinion were used to profile a possible damaging event. It is important to stress that historical data concerned mainly damaging events: this tends to underestimate event occurrence probability but provides useful information on physical effects, in terms of damage and disruption.

The Swiss Method (Heinimann et al., 1998; Raetzo et al., 2002) was then applied to better characterize Plan Pezziè scenario, to identify the hazard levels, and to map their spatial distribution on a more detailed scale, according to landslide magnitude and frequency. The Geological, Hydrological and Torrent Control Offices of the Autonomous Province of Bolzano (where the study area is located) drafted guidelines for hazard assessment derived from rules adopted in Switzerland in the last decade for the definition of hydrogeological hazards in Swiss cantonal master plans.

Starting from available information (cartographic data, aerial photographs, historical data, existing database, etc.), and according to the Swiss Method (Fig. 5), landslide hazard levels were derived for Plan Pezziè scenario, using a matrix that combines the following parameters:

1. Intensity. This parameter is computed by estimating the geometric severity and the expected velocity of the landslide. The geometric severity is strongly controlled by the thickness of the involved material and can be expressed by three classes: low $(<2 \mathrm{~m})$; medium $(2-$ $10 \mathrm{~m})$; high $(>10 \mathrm{~m})$. The velocity can be subdivided in three classes using the Cruden and Varnes classification (1996): from extremely slow to slow ( $<13 \mathrm{~m} / \mathrm{month})$; from moderate to rapid $(13 \mathrm{~m} / \mathrm{month}-1.8 \mathrm{~m} / \mathrm{h})$; from very rapid to extremely rapid $(>3 \mathrm{~m} / \mathrm{min})$.

2. Frequency. This factor can be classified into four classes: high ( $<30$ years); medium (30-100 years); low (100-300 years); very low ( $>300$ years).

Combining intensity and frequency classes, hazard levels were obtained.

This step is followed by detailed analysis focused to spatially identify and to characterise vulnerable elements in the study area, and to provide an understanding of the possible physical effects on exposed elements caused by the impact of a potentially destructive event. It was achieved by analysing both aerial photographs (at a 1:10000 scale) and other available technical maps; the geometric features (shapes, perimeters, areas and, eventually, volumes) and the relevant descriptive attributes (as occupancy rates of buildings, traffic flows, etc.) were collected and stored by analysing cadastral maps and other technical documents; systematic in-situ surveys and measures were also performed. A considerable amount of data was provided by the Autonomous Province of Bolzano and ASTAT (Provincial Statistic Institute). The following elements were identified and inventoried:

1. Infrastructure: roads, gas pipelines, power lines, water lines, penstocks, sewers, and ski facilities. Types, struc- tural characteristics, reparation cost, and cost to get temporary structures ready were derived for each infrastructure and stored in the database;

2. Buildings: use (residential, commercial, tourist, etc.), structural characteristics, number of floors, areas, volumes, number of residents, and occupancy rates. The number of residents and the occupancy rates are useful to approximately define the casualties, if the buildings collapse, and to define homelessness if they become uninhabitable. Market values, insured values, and construction cost were also obtained.

Within engineering and natural science, vulnerability is traditionally defined as the degree of loss to a given asset (or set of assets) at risk from a damaging event. People's life and health, buildings, infrastructure, and activities are at risk when submitted to a destructive event. In this study, vulnerability describes in qualitative terms the expected physical effects: the aesthetic, functional, and structural damage (Cardinali et al., 2002) suffered by the exposed elements. For aesthetic damage, it is assumed that the functionality of buildings and infrastructures is not compromised, and the damage can be repaired rapidly and at low cost; for functional damage, the functionality of the exposed elements is compromised, and the damage may take time and resources to be fixed; for structural damage, the elements are severely or completely damaged: time and large resources are required to carry out demolition and reconstruction work.

Data derived from written reports and literature about historical damage and disruption suffered by population, buildings, infrastructure, and economic activities, during past "similar" landslide events, and the geometric and structural characteristics of the elements potentially affected was crucial for the definition of Plan Pezziè vulnerability scenario. At the same time, the local experience together with interviews of the people affected by past disasters were used to understand past physical effects.

Finally, an indicative level of risk to assets was defined (Plan Pezziè risk scenario) combining the hazard level and the expected degree of physical effects. Five classes of risk were defined (from "very low" to "very high"), each of them is associated with some general examples of possible implications.

In the last step, an estimate of the prospective social and economic consequences was performed within the profiled risk scenario, analysing the relationships between the event, its physical effects (damage and disruption) and its economic consequences (direct and indirect losses). Although it should include all the types of losses, the risk analysis proposed in the study will consider only tangible losses, related to physical damage to assets, because of the real difficulty to quantify the intangible losses.

In achieving this aim, the social and economic characteristics and trends of the study area were analysed. Social analysis characterised the human presence and its evolution over 
time (inhabitants, distribution of age, "rate of activity", commuting, etc.). Economic analysis evaluated the assets in the exposed area, the activities carried out there (firms, jobs and sectors of local economy), and the flow of goods and commodities. In this study, the potential losses will be described in terms of "direct losses", if damage is directly connected to the assets affected by the phenomenon, and "indirect losses", if damage is related to the interruption or to the reduction of economic activity (i.e. loss of production, revenues, etc.).

Direct losses were evaluated within each area at risk (as suggested by AGS, 2000), in relation to the spatial distribution of the vulnerable assets, and to a thickness of the piled-up debris varying from $1.0 \mathrm{~m}$ up to $2.0 \mathrm{~m}$. The estimate of the direct losses was followed by evaluation of the indirect damage. Because this is a highly tourist area, indirect losses may include a reduction in hotel revenues, due to a decrease in the tourist flow, both for hotels directly involved and hotels not damaged but potentially affected by closure of the national road. The evaluation of indirect losses was performed analysing available data related to previous summer/winter seasons to statistically obtain the potential number of tourists, an average value of consumer expenditures, and the occupancy rates of hotels, for each week included in temporal scenarios. Effects on the transport of goods and commodities were also analysed.

\section{Study area: the municipality of Corvara in Badia, Italy}

The municipality of Corvara in Badia (Figs. 1a, 1b) is located in the central Dolomites (south-eastern Italian Alps), within the Autonomous Province of Bolzano (Italy). This mountainous area is characterised by high altitude differences, due to dolomitic massifs higher than $3000 \mathrm{~m}$ and valley floors at about $1500 \mathrm{~m}$.

This sector of the Dolomites has been investigated in the framework of several European Projects for many years (EPOCH, 1994; NEWTECH, 1998; GETS, 2001; ALARM, 2004). The available data, collected through field surveys, measuring instruments and monitoring systems, represent this area as widely affected by gravitational phenomena. Some mass movements occurred in the last early post-glacial period, following the retreat of the Würmian glaciers. Many of them were reactivated in the Holocene, during periods of intense climatic variations (Corsini et al., 2001; Soldati et al., 2004).

The geomorphologic features of the area are highly related to the different physical and mechanical properties of the outcropping geological units, to the tectonic structures (related to intense and different tectonic phases), to the modelling activity of the Pleistocene glaciers (with frost shattering, rill-wash erosion, etc.), and to the gravitational slope processes (Corsini et al., 1998). Clear geomorphological evidence of mass movements can be found within the munici- pality of Corvara in Badia and its surroundings, where landslides, characterised by different types, materials involved, volumes, velocities, degrees of activity, and return periods are widely distributed (Panizza et al., 2002). Some of them are of considerable dimensions and still active.

Because of the scenic beauty and skiing terrain, the area has undergone an intense tourist development. Indeed, Corvara in Badia is one of the best-known sites in the Alps for skiing and hiking. The urban settlement has progressively increased since the late 1960s, and a dense network of facilities now serves most of the slopes. This development has significantly increased both the wealth of the area and risk to slope failures.

Within the municipality of Corvara in Badia, Plan Pezziè area (an administrative division of the municipality) was chosen as a test-site. It was affected by dormant low thickness earth-debris flows, usually following periods of heavy and/or prolonged rainfalls, that have posed threats to the community, buildings, infrastructure and environment in the past years. As aforementioned, the central sector of Plan Pezziè area was chosen to be analysed in more detail in this study.

\subsection{Plan Pezziè database}

The physical structure of the spatial database was designed by a research team from the University of Milano-Bicocca and National Research Council of Italy (research partners in "ALARM") to exploit the data processing capabilities of Geographic Information Systems (GIS) and the potentialities of the Relational Database Management Systems (RDBMS). A multi-scale database was determined to be the most functional tool for managing geometric, descriptive and topological information, originally gathered at different scales (from 1: 50000 up to $1: 5000$ ).

The spatial database was populated by the scientists from the University of Modena (a research partner in "ALARM"). The aim was to collect, integrate, manage and analyse all existing data related to the study area and derived from different sources, characterized by different degrees of accuracy.

All georeferenced information stored in the database as maps (both in vector and raster format) and related tables was completely available on demand and usable for each phase of the study, justifying the great efforts involved in database creation, maintenance and updating.

To perform the risk analysis, the following data was collected, critically reviewed, and stored in the database:

1. Geological maps (1:50000 to $1: 10000)$ portraying information about the main geological units. The different rock compositions and textures affect slope instability, influencing strength, permeability, and susceptibility to chemical and physical weathering of the rock masses (source: Modena research partner);

2. Structural maps (1:50000 to 1:10000), representing the structural setting of the study area. Features such 
as sequence and type of layering, lithologic changes, planes, joints, faults and folds are accountable for slope instability (source: Modena research partner);

3. Land use maps (1:25000 to $1: 10000)$ indicating land use units. These may affect hydrological conditions and soil strength (source: Modena research partner);

4. Maps of superficial deposits (1:25000 to 1:10 000), describing the types and the physical and mechanical characteristics of unconsolidated deposits (source: Modena research partner);

5. A Digital Elevation Model $(20 \times 20 \mathrm{~m})$, provided by the Autonomous Province of Bolzano. Raster datasets $(20 \times 20 \mathrm{~m})$ on morphometric features (altitude, internal relief, slope angle, aspect, longitudinal and transverse slope curvature and slope roughness) and on hydrologic parameters (watershed area, drainage density, drainage network order, channel length, etc.) were automatically extracted from the DEM by the Milano research partner;

6. A detailed landslide inventory map (1:10000), showing the geographical distribution of mass movements. Landslides were classified in terms of types, materials involved, estimated volumes and velocities, degrees of activity, and return periods; distinctions were made between source and depositional areas (source: Modena research partner);

7. Susceptibility and hazard maps (1:25000 to 1:5000), obtained by statistical modeling (Weights of Evidence Modeling Technique) and by the rules adopted in Switzerland for the definition of hydrogeological hazard in cantonal master plans by the Federal Office for Water and Geology (Swiss Method); these maps were obtained by a joint collaboration between the Modena and Milano research partners;

8. Maps of vulnerable elements (1:10000 to 1:5000), containing information on the spatial distribution and attributes of public and private buildings, network facilities, and economic activities in the area. Documentation of injuries, property damage, economic disruption, relief and repair cost, and environmental consequences concerning past events was also collected and stored as key requirements in the process of understanding prospective losses, if similar events occur again in the future (source: Milano research partner).

9. Social and economic characteristics and trends of the study area: a systematic survey enabled the creation of a social, demographic and economic profile of the community at risk (source: Milano research partner).

\section{Results}

\subsection{Plan Pezziè hazard scenario}

Within the municipality of Corvara in Badia several natural processes act on the landscape and threaten the community, buildings, infrastructure and environment. Landslide susceptibility maps together with maps of vulnerable elements described Plan Pezziè area as a "critical zone": an area classified as highly susceptible with the presence of elements at risk. In effect, many debris flows have affected in the past years (and could affect in the future) the territory and its community. In particular, historical records (Table 1), local news, and interviews of local people suggested the central sector of this area as a potential source of danger. We decided to choose it as a suitable test-site (Plan Pezziè hazard scenario) for an initial application of the methodology proposed in this study.

On a more detailed scale, all available information was used to better characterise the hazard scenario, obtaining a spatial distribution of areas of different hazard levels based on landslide magnitude and frequency.

According to the Swiss rules (Fig. 5), a medium to high value of intensity was defined for the source area $\left(107496 \mathrm{~m}^{2}\right)$, considering a low geometric severity (related to a low thickness of the involved materials), and velocity rates from very to extremely rapid. Available data and expert opinion suggested indicative return periods lower than 30 years. A level of hazard equal to $\mathrm{H} 4$ was derived. The depositional area $\left(618349 \mathrm{~m}^{2}\right)$ was characterised by a moderate intensity value in relation to a moderate to rapid velocity rate and a moderate geometric severity. Two different indicative return periods were defined: the former was between 30 and 100 years: a hazard level equal to $\mathrm{H} 3$ was derived. The latter was between 100 and 300 years and it was related to an area partially sheltered from debris flows by means of anthropic mitigation/protection structures (drainpipes and defensive containment works): $\mathrm{H} 2$ was considered as the appropriate hazard level (Fig. 6).

\subsection{Plan Pezziè vulnerability scenario}

In this study, vulnerability was expressed using a heuristic (qualitative) scale considering the physical effects on builtup areas and infrastructure. Hotels, public and private buildings, national and local roads, water lines and penstocks were considered vulnerable by the profiled fast-moving earthdebris flow. Damage to the vulnerable assets was inferred within each hazardous area, considering an estimated thickness of the piled-up debris varying from $1.0 \mathrm{~m}$ up to $2.0 \mathrm{~m}$ (the lower thickness was used in areas sheltered by protection structures). Moreover, damage was defined independently for each different type of elements at risk and both the time required to recover and/or restore the damage and 


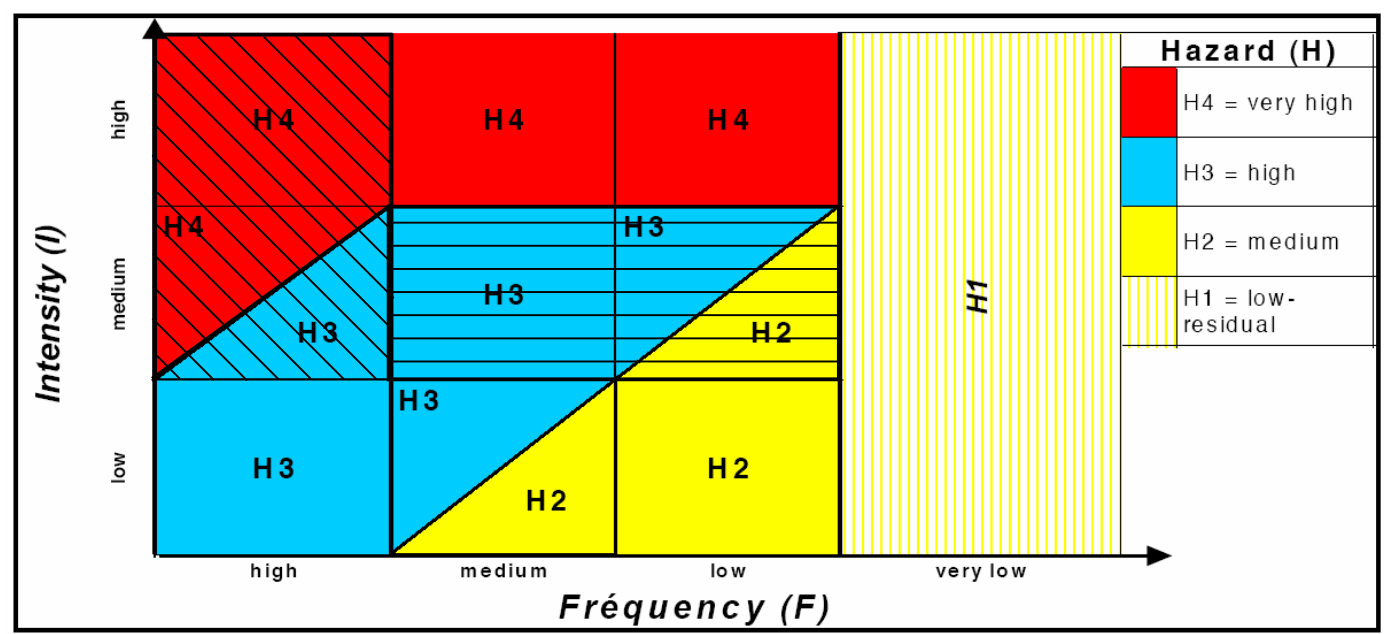

Fig. 5. Swiss Method matrix (source: Heinimann et al., 1998; Raetzo et al., 2002) for the definition of hazard levels (intensity vs frequency). Diagonal and horizontal crossed lines represent hazard levels assigned to the source and to the depositional areas within Plan Pezziè scenario, respectively.

Table 2. Prospective physical effects due to the occurrence of the profiled event. Vulnerability of built-up areas and infrastructure is heuristically described in terms of aesthetical (minor), functional, and structural damage.

\begin{tabular}{llll}
\hline & $\begin{array}{l}\text { Hotels, private and } \\
\text { public buildings }\end{array}$ & $\begin{array}{l}\text { National and local } \\
\text { roads }\end{array}$ & $\begin{array}{l}\text { Water lines and } \\
\text { penstocks }\end{array}$ \\
\hline $\begin{array}{l}\text { Aesthetic or } \\
\text { minor damage }\end{array}$ & Damage to outer walls & $\begin{array}{l}\text { Damage to road signs and } \\
\text { guardrails }\end{array}$ & Covering by debris material \\
$\begin{array}{l}\text { Functional } \\
\text { damage }\end{array}$ & Damage to inner walls & Covering by debris material & $\begin{array}{l}\text { Damage to pipes and pipe } \\
\text { fittings }\end{array}$ \\
& $\begin{array}{l}\text { Ground floor filling up } \\
\text { Damage to furniture } \\
\text { Damage to electric plants }\end{array}$ & & \\
$\begin{array}{l}\text { Structural } \\
\text { damage }\end{array}$ & Damage to doors and windows & & No \\
\hline
\end{tabular}

the importance of the elements at risk to the potential users were considered.

In Plan Pezziè scenario, no elements at risk are located in the source area (H4) where structural damage would be expected. Given the physical characteristics of the potential event, a rapid destruction of buildings and infrastructure would be quite possible and people are at risk of injury both inside and outside buildings: an area where development should be strongly prohibited. In the upper part of the depositional area (H3), functional damage to buildings should be expected, but not destructions as long as the construction type was adapted to the present conditions; people are at risk of injury outside buildings. Land use planning and appropriate protective measures were put into practice to decrease the hazard level. In the lower part of the depositional area (H2), functional/aesthetic damage to buildings is possible and people are at a low risk of injury outside buildings. This area is mainly an alerting domain, where people should be notified of the possible risks.

Specifically, in regard to the hotels, private and public buildings, it was assumed that the earth-debris flow may fill up the ground floors ( 1.0 to $2.0 \mathrm{~m}$, in relation to position of 


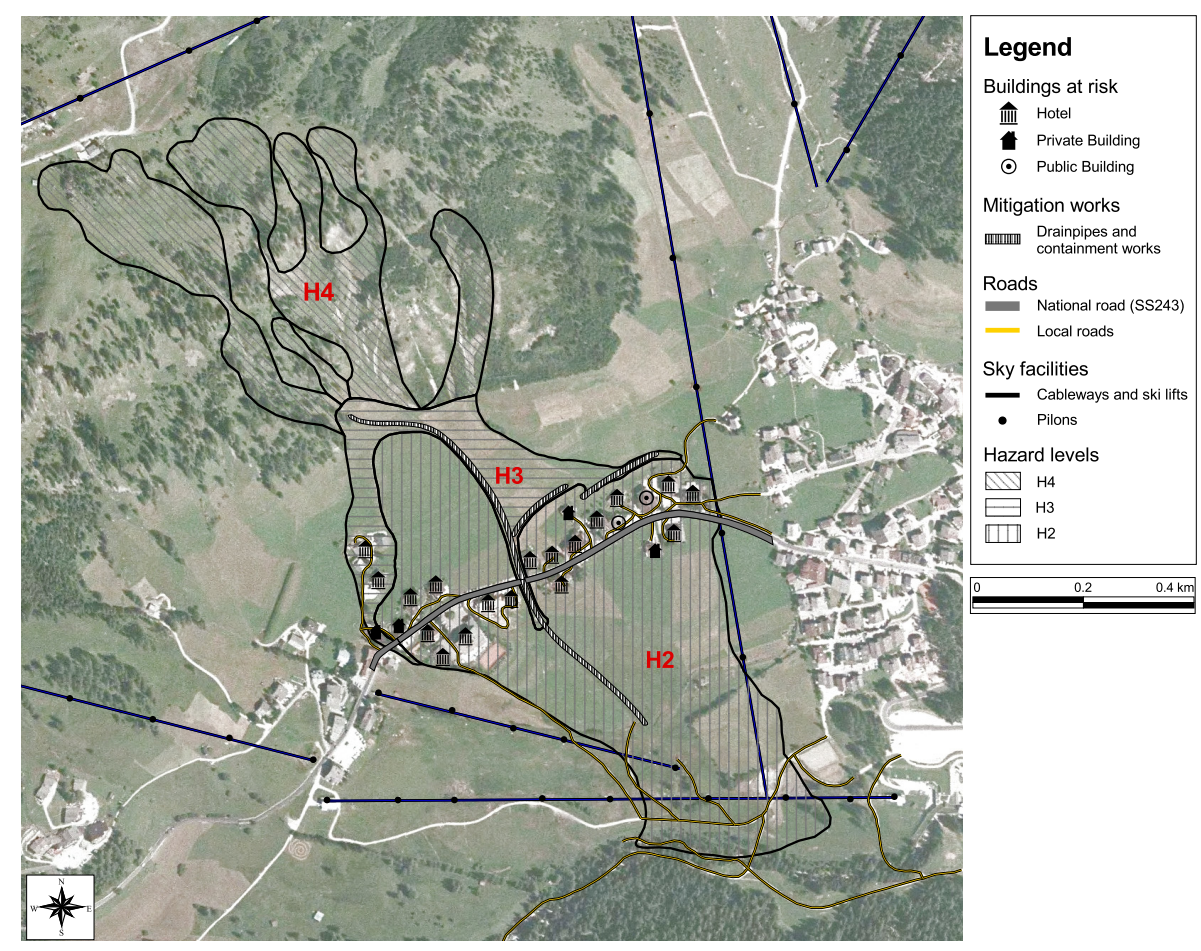

Fig. 6. Plan Pezziè hazard scenario. Crossed lines represent the spatial distribution of hazard levels assigned to the source and to the depositional areas (royalties on Digital Orthophoto: Autonomous Province of Bolzano-Autonome Provinz Bozen-Sudtirol).

the affected elements), causing damage to furniture, electric plants, and door and windows frames. Both inside and outside walls are affected, requiring cleaning up, waterproofing, whitewashing/plastering and painting operations. Damage to transportation network was also considered. For national and local roads no destruction was expected and, considering the event characteristics, the traffic could be interrupted for a short period (2 to 3 days), determining a longer travel time. Both water lines and penstocks could be affected, loosing their function for a short time interval (Table 2).

\subsection{Plan Pezziè risk scenario}

Finally, an indicative level of risk to assets was defined (Plan Pezziè risk scenario), combining the hazard level and the degree of physical effects due to the expected damaging event (Table 3). The former ranges from $\mathrm{H} 2$ (for the depositional area) to $\mathrm{H} 4$ (for the source area). The latter varies from "aesthetic" to "functional", in relation to the type and to the spatial location of the vulnerable elements, moving from the lower part of the depositional area up to the built-up sectors. The resulting level of risk may be qualitatively estimated as follow (Figs. 7, 8):

- Very low: this level of risk was selected for all sectors without elements at risk, apart from the hazard level.

- Low: this level of risk was assigned to the lower part of the depositional area (H2) where local roads and ski
Table 3. Qualitative estimation of the risk level in the study area based on hazard levels and physical effects. Hazard level $\mathrm{H} 2$ involves two different risk levels on the base of the type of the elements at risk and of their spatial location in relation to the source of danger.

\begin{tabular}{lcc}
\hline Hazard level & Physical effects & Risk level \\
\hline H1 & Aesthetic damage & Very Low Risk \\
H2 & Aesthetic damage & Low Risk \\
H2 & Functional damage & Moderate Risk \\
H3 & Functional damage & High Risk \\
H4 & Structural damage & Very High Risk \\
\hline
\end{tabular}

facilities were located. Engineers, architects and land surveyors suggested a low level of risk: the spatial location of the elements at risk made them not accountable for severe physical effects.

- Moderate: this level of risk was assigned to the areas characterised by a hazard level equal to $\mathrm{H} 2$ and by the presence of many elements at risk directly related to the social and economic activities. In this area functional/aesthetic damage would be expected.

- High: this level of risk was assigned to the westernmost 
Table 4. Values $\left(€ / \mathrm{m}^{2}\right.$ and $\left.€ / \mathrm{m}^{3}\right)$ used in economic analysis to quantify direct damage affecting hotels, private houses and public buildings.

\begin{tabular}{|c|c|c|c|c|}
\hline & Operations and cost & Hotels & $\begin{array}{l}\text { Private } \\
\text { houses }\end{array}$ & $\begin{array}{c}\text { Public } \\
\text { buildings }\end{array}$ \\
\hline \multirow{5}{*}{ 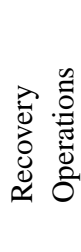 } & Demolition of walls $\left(€ / \mathrm{m}^{2}\right)$ & 87 & 87 & 87 \\
\hline & Reconstruction of walls $\left(€ / \mathrm{m}^{2}\right)$ & 67 & 67 & 67 \\
\hline & Debris excavation $\left(€ / \mathrm{m}^{3}\right)$ & 52 & 52 & 52 \\
\hline & Debris removal $\left(€ / \mathrm{m}^{3}\right)$ & 25.5 & 25.5 & 25.5 \\
\hline & Transportation and storage $\left(€ / \mathrm{m}^{3}\right)$ & 26 & 26 & 26 \\
\hline \multirow{4}{*}{ 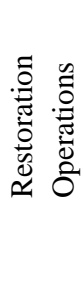 } & Inner walls cleaning up, waterproofing, & 7 & 7 & 7 \\
\hline & $\begin{array}{l}\text { whitewashing/plastering and painting }\left(€ / \mathrm{m}^{2}\right) \\
\text { Outer walls cleaning up, waterproofing } \\
\text { and quartz painting }\left(€ / \mathrm{m}^{2}\right)\end{array}$ & 10 & 10 & 10 \\
\hline & Restore electric plants $\left(€ / \mathrm{m}^{3}\right)$ & 25 & 22 & 22 \\
\hline & $\begin{array}{l}\text { Restore and replace furniture and door } \\
\text { and window frames }\left(€ / \mathrm{m}^{2}\right)\end{array}$ & $400-600$ & $300-400$ & $400-600$ \\
\hline
\end{tabular}

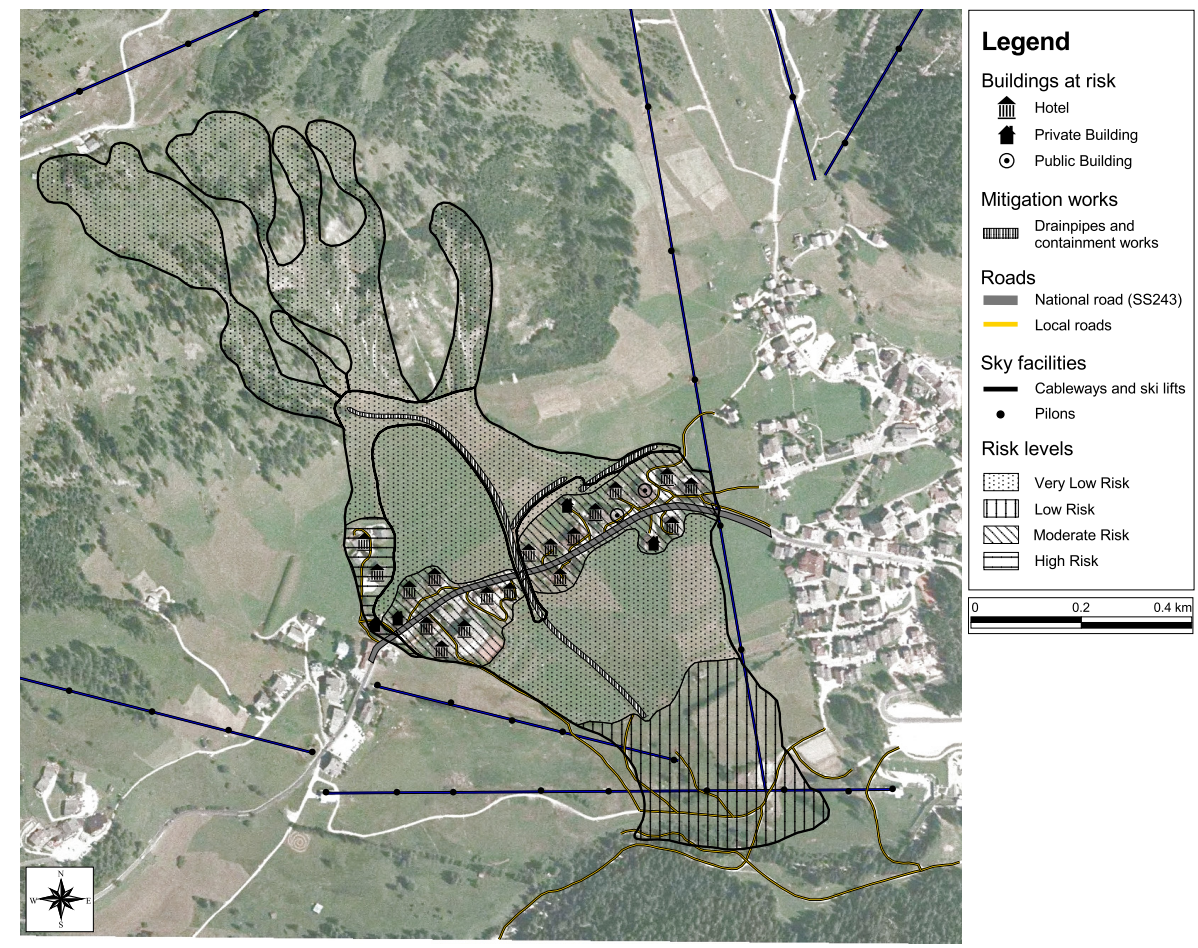

Fig. 7. Plan Pezziè risk scenario. Crossed lines represent the spatial distribution of risk levels (royalties on Digital Orthophoto: Autonomous Province of Bolzano-Autonome Provinz Bozen-Sudtirol).

sector of the scenario (H3). In spite of the presence of mitigation/protection structures, local experts did not consider this area as safe as the one aforementioned.

In our scenario there are no areas characterised by a very high level of risk.

\subsection{Economic consequence analysis}

In the last step, an estimate of the prospective economic consequences was performed. Available historical data does not account for structural damage requiring the partial or complete destruction/reconstruction of the elements at risk, given 


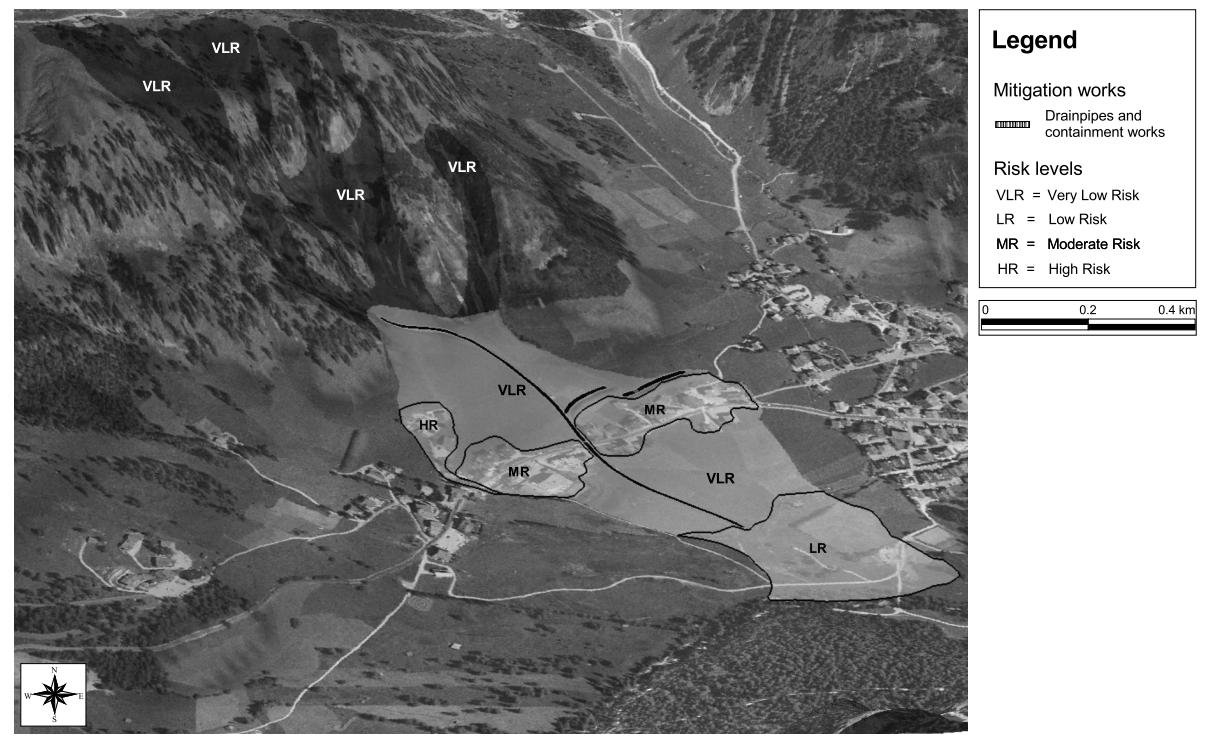

Fig. 8. 3-D representation of the spatial distribution of risk levels. Dark and light sectors symbolize the source and the depositional areas of the earth-debris flow, respectively (royalties on Digital Elevation Model and Digital Orthophoto: Autonomous Province of BolzanoAutonome Provinz Bozen-Sudtirol).

the physical characteristics of the damaging phenomenon and the presence of protection structures. For this reason, only functional and/or aesthetic damage, that requires recovery and restoration operations, was considered. Recovery operations involve debris removal, transportation to and accumulation in waste disposal areas; restoration operations are different in relation to the affected elements (as listed in Tables 4 and 5).

Market values, insured values, construction and repair cost, and available indexes (expressed in $/ \mathrm{m}, / \mathrm{m}^{2}, / \mathrm{m}^{3}$, or in $\%$, and derived from empirical estimates made by engineers, architects, land surveyors, and from interviews of local building companies), were applied to the vulnerable assets (Tables 4,5 ) to obtain an expected monetary equivalent.

As listed in Tables 6, 7 and 8, the total amount of estimated direct damage may be quantified in 8913000 . Power lines, gas pipelines, and sewers were excluded from the assets at risk because they are buried and not subject to damage. The position of ski facilities in the outermost part of the depositional area makes them probably safe from risk (they are about $370 \mathrm{~m}$ away from the nearest buildings).

The estimate of direct losses was followed by an economic evaluation of indirect damage. Two different temporal scenarios were considered; the first is during the autumn season, positing a damaging event between October and the end of November. Historical data report landslide events at this time. Autumn is not a tourist season but considering an expected closing time of 60 to 120 days for eighteen affected hotels, consequences could be extended into the winter tourist season. The expected closing time was based on the potential number of affected structures, on the adverse
Table 5. Values ( $€ / \mathrm{m}, € / \mathrm{m}^{3}$ and $\%$ ) used in economic analysis to quantify direct damage affecting roads, water pipes and penstocks.

\begin{tabular}{|c|c|c|}
\hline & Operations and cost & \\
\hline \multirow{3}{*}{ 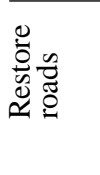 } & Debris excavation $\left(€ / \mathrm{m}^{3}\right)$ & 17 \\
\hline & Debris removal $\left(€ / \mathrm{m}^{3}\right)$ & 25.5 \\
\hline & Transportation and storage $\left(€ / \mathrm{m}^{3}\right)$ & 26 \\
\hline \multirow{3}{*}{ 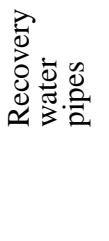 } & $\begin{array}{l}\text { Temporary solution to allow the flow- } \\
\text { manifolds and PVC pipes- }(€ / \mathrm{m})\end{array}$ & 5.5 \\
\hline & $\begin{array}{l}\text { Replacement of damaged stretches- } \\
\text { spheroidal cast iron pipes- }(€ / m)\end{array}$ & 46.3 \\
\hline & Additional cost for pipe fittings (\%) & 35 \\
\hline \multirow{3}{*}{ 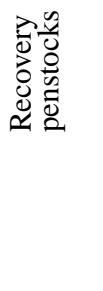 } & $\begin{array}{l}\text { Temporary solution to allow the flow- } \\
\text { manifolds and PVC pipes- }(€ / \mathrm{m})\end{array}$ & 5.4 \\
\hline & $\begin{array}{l}\text { Replacement of damaged stretches- } \\
\text { spheroidal cast iron pipes for } \\
\text { hydrostatic pressure- }(€ / m)\end{array}$ & 18.1 \\
\hline & Additional cost for pipe fittings (\%) & 35 \\
\hline
\end{tabular}

weather conditions during the winter season, and on the number of local building companies able to recover/restore buildings according to local rules and codes. Considering this temporal scenario and estimating 2 to 3 days as the time necessary for restoring the national road, the hotels not directly involved would not suffer a significant reduction in revenues. 
Table 6. Estimated total direct cost for hotels, private houses and public buildings in areas affected by different risk levels $(\mathrm{MR}=\mathrm{Moderate}$ Risk; HR = High Risk)

\begin{tabular}{|c|c|c|c|c|c|}
\hline & \multicolumn{5}{|c|}{ Affected buildings } \\
\hline & \multicolumn{2}{|c|}{ Hotels } & \multicolumn{2}{|c|}{ Private } & Public \\
\hline Total number of elements at risk & \multicolumn{2}{|c|}{18} & \multicolumn{2}{|c|}{4} & 2 \\
\hline Total area of the ground floors $\left(\mathrm{m}^{2}\right)$ & \multicolumn{2}{|c|}{6948} & \multicolumn{2}{|c|}{1305} & 731 \\
\hline \multirow[t]{4}{*}{ Total volume of the ground floors $\left(\mathrm{m}^{3}\right)$} & \multicolumn{2}{|c|}{18760} & \multicolumn{2}{|c|}{3525} & 1974 \\
\hline & \multicolumn{5}{|c|}{ Risk level } \\
\hline & \multicolumn{2}{|c|}{ Hotels } & \multicolumn{2}{|c|}{ Private } & Public \\
\hline & MR & HR & MR & HR & MR \\
\hline Number of elements at risk & 16 & 2 & 3 & 1 & 2 \\
\hline Area of the ground floors $\left(\mathrm{m}^{2}\right)$ & 6201 & 747 & 1050 & 255 & 731 \\
\hline Volume of the ground floors $\left(\mathrm{m}^{3}\right)$ & 16743 & 2017 & 2835 & 690 & 1974 \\
\hline $\begin{array}{l}\text { Remove, transport, and accumulate debris in } \\
\text { a waste area }(€)\end{array}$ & 590864 & 259070 & 75198 & 119185 & 92172 \\
\hline $\begin{array}{l}\text { Clean up, waterproof, whitewash/plaster and } \\
\text { paint walls }(€)\end{array}$ & 159474 & 40287 & 16006 & 15058 & 11081 \\
\hline Remake electric plants $(€)$ & 384615 & 84375 & 43065 & 34155 & 52807 \\
\hline Restore furniture, door and window fixtures $(€)$ & 3418800 & 750000 & 435000 & 345000 & 533400 \\
\hline Total cost $(€)$ & 4553753 & 1133732 & 569269 & 513398 & 689460 \\
\hline
\end{tabular}

Table 7. Estimated total direct cost for roads crossing areas affected by different risk levels $(\mathrm{LR}=\mathrm{Low}$ Risk; MR = Moderate Risk; HR = High Risk).

\begin{tabular}{|c|c|c|c|c|c|}
\hline & \multicolumn{5}{|c|}{ Affected roads } \\
\hline & Nation & 1 road & & Local road & \\
\hline \multirow[t]{4}{*}{ Total length (m) } & \multicolumn{2}{|c|}{522} & \multicolumn{3}{|c|}{1848} \\
\hline & \multicolumn{5}{|c|}{ Risk level } \\
\hline & \multicolumn{2}{|c|}{ National road } & \multicolumn{3}{|c|}{ Local roads } \\
\hline & MR & HR & LR & MR & HR \\
\hline Length (m) & 485 & 37 & 713 & 959 & 176 \\
\hline $\begin{array}{l}\text { Recover the structure } \\
\text { and restore the original } \\
\text { practicability conditions }(€)\end{array}$ & 282220 & 21530 & 414890 & 558033 & 102413 \\
\hline Total cost $(€)$ & 282220 & 21530 & 414890 & 558033 & 102413 \\
\hline
\end{tabular}

In the autumn scenario, indirect damage related to the closing period of the hotels directly involved may be quantified at 4675000 (if a 60 days interruption of activity is considered) or 9350000 (if a 120 days interruption of the activities is assumed).

As for private buildings, indirect cost is related to the reallocation of the families living in the four involved houses. At this time, it is difficult to evaluate the amount of indirect cost, due to a lack of information. More data should be collected through interviews of the families potentially in- volved. In this way it would be possible to verify if they own other houses in the neighbourhood of Corvara, or if they are obliged to choose a temporary accommodation during the disaster management period.

Indirect consequences should be quantified for public buildings (a bank office and the Town Hall). Both these services could be considered not essential in the aftermath of disaster, and the interruption of their activities probably should not cause serious consequences in terms of indirect cost. If the Town Hall is declared inaccessible for a short 
time, its facilities can be moved to other buildings not directly affected by the event. Similar considerations may be done for the bank office; other offices of the same banking company, located within few kilometres, may accomplish loan and credit operations.

The interruption of the national road (SS 243) may cause an increase in transportation cost of goods and commodities equal to 34.5 for a longer travel space of about $24 \mathrm{~km}$ (own elaboration from Gamba, 2002): in effects, vehicles coming from the Gardena Pass have to choose alternative routes to Corvara. Considering an interruption of 2 to 3 days and an average traffic flow of about 73 trucks and vans per-day, it is possible to estimate an increase in transportation cost of about 15000 .

Considering the time required to perform recovery/restoration operations, indirect damage are mainly caused by the decreased number of tourists in hotels directly involved. This outcome may be explained considering the temporal scenario: autumn is not a tourist season and the occurrence of a landslide should not determine severe consequences for the hotels that do not suffer physical damage. In this scenario, direct damage is comparable to the indirect one (especially if a recovery time of 120 days is considered).

Damage to the local ski facilities were not considered. But if they are affected by severe damage that cause a delay in the opening date of the winter ski season, indirect damage will be higher than the direct ones. In effect, socio-economic analysis showed that most of the winter tourists are involved in skiing activities. The consequence of the decrease in tourist flow may affect the entire ski-district, given the strategic importance of these ski facilities. They are part of the ski-tour of the four Dolomite Passes which joins four Ladin valleys: Gardena, Badia, Fassa, and Arabba, covering a total length of $40 \mathrm{~km}$.

The second temporal scenario is during the summer season, from July to August. Historical records report debris flows triggered by rainfall of short duration and high intensity. Because this is a period of high tourist flow, severe economic consequences would immediately affect hotels both directly and indirectly.

For hotels directly involved, we considered between 60 to 90 days to perform recovery/restoration operations; for a 60 day-scenario, the outcome of the analysis lead to an indirect cost of about 2840000 ; this result grows up to more than 4260000 if a 90 day-scenario is considered. 90 days was preferred to 120 days (autumnal scenario) considering that good weather conditions should reduce the number of recovery days.

For hotels indirectly involved, damage is caused by the reduction of the tourist flow, due to the interruption of the national road (SS243). Statistical data (analysed by the local tourist agency), highlighted:

1. $95 \%$ of the summer tourists would stay in Corvara one
Table 8. Estimated total direct cost for water lines and penstocks in areas affected by different risk levels (MR = Moderate Risk; HR = High Risk).

\begin{tabular}{lcc}
\hline & \multicolumn{2}{c}{ Affected structures } \\
\hline & Water lines & Penstocks \\
Total length (m) & 945 & 256 \\
& \multicolumn{2}{c}{ Risk level } \\
& Water lines & Penstocks \\
& MR & HR \\
$\begin{array}{l}\text { Temporary solution to keep the flow } \\
\text { (manifolds and PVC pipe fittings)( }())\end{array}$ & 7080 & 1866 \\
$\begin{array}{l}\text { Replacement of damaged stretches } \\
\text { (spheroidal cast iron pipe) }(€)\end{array}$ & 59118 & 6248 \\
\begin{tabular}{l} 
Total cost $(€)$ \\
\hline
\end{tabular} & 66198 & 8114 \\
\hline
\end{tabular}

week. It is reasonable that they will choose to reach Corvara even if they have to increase their travelling time and cost.

2. $5 \%$ of the summer tourists would spend only a weekend in Corvara. It is reasonable to assume that about $20 \%$ of the tourists will not reach Corvara changing their holiday destination (according to their behavioural preference, Machina, 1982). This figure cannot be considered as a critical situation able to affect indirect losses.

The increase in cost for goods and commodities transport may be similar to the autumnal scenario, considering a comparable average traffic flow. Similar considerations can be done for private and public buildings.

Finally, it is possible to highlight that also during a summer event, indirect damage mainly derives from a decrease in the tourist flow to hotels directly involved.

\section{Uncertainties}

Many input parameters used in this study are characterised by an inherent degree of variability and uncertainty and this has always to be considered when discussing risk analysis results. End users have to clearly understand the degree of uncertainty related to each parameter, the origin and the significance of this uncertainty, and the implication that it has on final results. In this study we inferred landslide magnitude and frequency from historical records, local interviews, and expert knowledge, experience, and judgement; and that certainly produced a medium to high level of uncertainty on final results.

Uncertainty also arises in the definition of vulnerability, which is characterised by several factors that need to be evaluated, many of these may not be readily quantifiable. So, if 
they are to be included in risk analysis, the role of knowledge and judgement may play a crucial role, as in this study, and vulnerability assessment becomes a somewhat subjective procedure.

A low level of uncertainty is related to economic analysis in terms of economic assessment of assets and trends in the study area. On the contrary, a high degree of uncertainty is related to the results of economic analysis (prospective consequences): in effect, they were derived considering pre-defined hazard and vulnerability scenarios, each of which characterised by many assumptions and estimates.

More detailed data is necessary to reduce the degree of uncertainty to an acceptable level; but, if that is impossible, sensitivity analyses should be performed to evaluate the effect of changing assumptions or estimates in each scenario; and this is the aim of future studies. Moreover, the developing of an advanced understanding of how mountain hydrogeomorphologic processes behave and the application of this understanding for long-term living with risk are among the topics of a new European Project (Mountain Risks: from prediction to management, 2007) in which the authors are involved together with eleven European teams.

Finally, as recommended by IUGS Working Group on Landslides-Committee on Risk Assessment (1997), Heinimann (1999), and Bell and Glade (2004a), the final results of a risk analysis should be treated as relative and not as absolute values.

\section{Conclusions}

The multi-disciplinary methodological approach proposed in this study is based on a "cause-effect" correlation, on the "scenario mapping" method, and on rules and assumptions derived from social and environmental economics useful to get an economic analysis of the prospective consequences. The "cause-effect" correlation was firstly analysed from a physical point of view. The cause, the natural event, was correlated to the effects, i.e. the aesthetic, functional, and structural damage to the exposed elements. Then, an understanding of the possible physical effects due to the occurrence of a damaging event allowed us to evaluate economic consequences in terms of direct and indirect losses. To achieve this aim we studied and analysed the assets allocated in the exposed area, the tourist flows, the transport of goods and commodities and the social and economic trends acting in the area. The study shows the importance of indirect losses, which are as significant in magnitude as direct losses.

The study was performed at a very local scale (1:5000$1: 10000)$ but the proposed methodology could be applied also to a cluster of neighbouring municipalities or to a wider administrative entity. This analysis was carried out through documentations of past events and their consequences in terms of property damage, economic disruption, relief and repair cost, and environmental consequences. This type of data was collected in municipal, provincial, regional, and national archives, often in digital format.

We pursued the following steps to achieve this aim:

1. The definition of a specific hazard scenario, with its own physical and geometric characteristics;

2. The inventory of the elements at risk and the study of the social and economic trends acting in the area;

3. The description and the analysis of the physical effects (vulnerability scenario), derived from the occurrence of a potentially damaging phenomenon;

4. The definition of an indicative risk scenario;

5. The estimate of the prospective social and economic consequences (direct and indirect damage), within the profiled risk scenario: the cost for recovery/restoration operations of assets involved, the reduction of revenues and the increase in cost were analysed.

The loss assessment performed in the study was not only a simple accounting of direct damage but also a more detailed loss analysis, focused to consider and quantify also the indirect economic consequences due to the event. In effect, the analysis shows the importance of indirect damage that is comparable to direct damage (Fig. 9). It is important to underline that, while direct damage is strictly related to the physical characteristics of the assets involved, indirect damage mainly depends on the role and importance of the assets in the local economy. Moreover, indirect damage affects a wider area than that directly involved in the landslide, and for a longer period of time.

Finally, in Plan Pezziè scenario a high correlation was found between direct and indirect losses and the frequency and the period of the year affected by the damaging event. As aforementioned, the frequency may be of great relevance in determining direct damage while the period of the year mostly affects indirect damage.

A risk analysis for this failure-prone area was considered an important process for:

1. Establishing a sound rationale for risk reduction programs based on historical economic and social impacts;

2. Evaluating the cost-effect ratio of proposed mitigation actions for this landslide-prone area;

3. Creating mechanisms for risk sharing involving the public and private sectors through insurance, special assessment districts, or other financial risk pooling;

4. Sharing responsibility for landslide-related cleanup, repair, and rehabilitation cost;

5. Understanding the non-economic consequences of a landslide event (environmental and psychological consequences). 


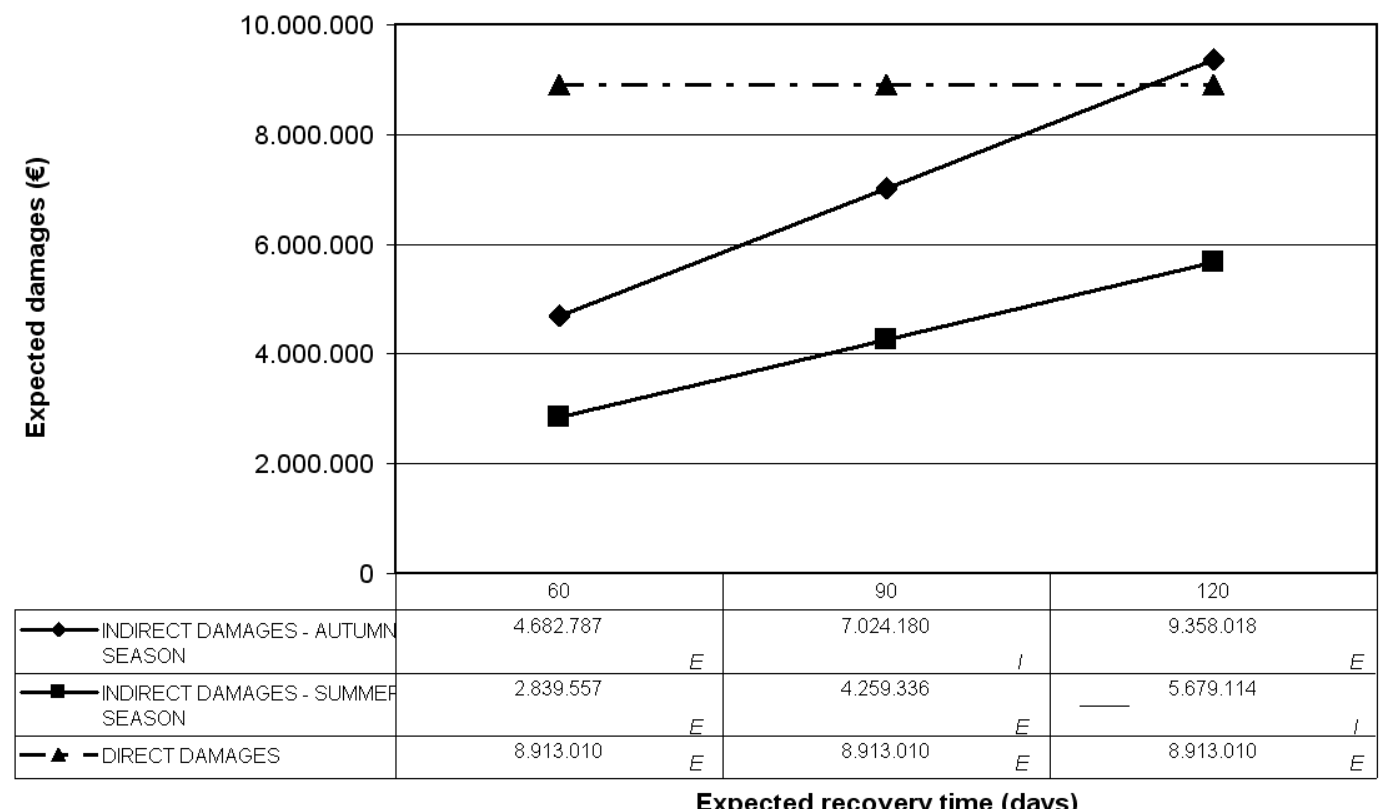

Expected recovery time (days)

Fig. 9. Direct and indirect damage for different scenarios. Values were estimated by economic analysis (E) or by interpolation (I).

A comprehension of the social and economic losses in Plan Pezziè scenario can be considered as crucial for future decisions on landslide risks. As articulated in the National Research Council "red book" (NRC, 1983), risk analysis is the first step to making decisions for managing a particular risk. As emphasized in a more recent NRC report (1996), risk analysis can be an important process (and not just a technical undertaking) to inform stakeholders about potential consequences and to gain consensus about appropriate steps to address potential harms. Moreover, it is our opinion that all the citizens should understand the risks they are faced with and actively take part in the definition of mitigation and prevention measures. Understanding the risk posed by potential landslides is a key point for determining appropriate risk management strategies. This aim can be achieved by assessing the cost of managing risk and the direct and indirect benefits and by optimising the allocations of available resources.

For this reason the results of a risk analysis are among the most valuable information for risk evaluators (dealing with risk perception and acceptance of the involved people) and risk managers (combining the results of risk analysis and risk evaluation to find the most appropriate solutions). In effect, the management of risk (planning, prevention, and mitigation measures) looks for the best trade-off between potential benefits (lack of loss) and cost for risk control and damage reduction. Coupling the earth scientists overview with the necessities of public administrators and decision makers, passing through economic theory (Varian, 1990), the management of risk is a function of balancing between the cost for risk control, its reduction to an acceptable level, and the potential benefits.
Despite all possible improvements, a certain degree of uncertainty will always remain in hazard and risk analysis, because of the uncertainties of each input factor. For this reason, the final results have to be treated as relative and not as absolute.

Acknowledgements. This paper is part of the European Commission Project "Assessment of Landslide Risk and Mitigation in Mountain Areas, ALARM" (contract EVG1-CT-200100038), Fifth Framework Programme. The authors are grateful to O. Maquaire and J.-P. Malet (University of Caen, BasseNormandie), G. L. Raines (USGS, Nevada), and T. Glade (University of Wien, Austria) whose pertinent comments and suggestions have improved the quality of this paper. Our special thanks belong to P. Reichenbach (CNR-IRPI, Italy) and to another anonymous reviewer for the helpful comments and suggestions on the manuscript. Finally, the study benefited greatly through the contributions of A. Corsini, M. Panizza and M. Soldati (Geological Department of the University of Modena, Italy).

Edited by: T. Glade

Reviewed by: P. Reichenbach and another anonymous referee

\section{References}

AGS: Australian Geomechanics Society Subcommittee on landslide Risk Management: Landslide Risk Management: Concepts and Guidelines, Australian Geomechanics Journal, 35, 1, 49-92, 2000.

Agterberg, F. P., Bonham-Carter, G. F., and Wright, D. F.: Weights of Evidence modelling: a new approach to mapping mineral potential, in: Statistical Applications in the Earth Sciences, edited 
by: Agterberg, F. P. and Bonham-Carter, G. F., Geological Survey of Canada, Paper 89-9, 171-183, 1989.

ALARM: Assessment of Landslide Risk and Mitigation in Mountain Areas, EC Contract No. EVG1-CT-2001-00038, 2004.

Ashby, G. L.: Development of a Risk Management Strategy for Part of State Highway 73 in the South Island of New Zealand, New Zealand Society for Risk Management Conference, Wellington, NZ, 2002.

Barneich, J., Majors, D., Moriwaki, Y., Kulkarni, R., and Davidson, R.: The Reliability Analysis of a Major Dam Project. Uncertainty in the Geologic Environment, from Theory to Practice. In Proceedings of Uncertainty 1996, Geotechnical Engineering Division, ASCE, 1367-1382, August 1996.

Bell, R. and Glade, T.: Quantitative risk analysis for landslides. Examples from Bíldudalur, NW-Iceland, Nat. Hazards Earth Syst. Sci., 4, 117-131, 2004a.

Bell, R. and Glade, T.: Multi-hazard Analysis in Natural Risk Assessment, in: International Conference on Computer Simulation in Risk Analysis and Hazard Mitigation, edited by: Brebbia, C. A.: WIT Press, 26-29 September, Rhodes (GR), 197-206, 2004b.

Blöchl, A. and Braun, B.: Economic assessment of landslide risk in the Swabian Alb, Germany-Research framework and first results of homeowners' and experts' surveys, Nat. Hazards Earth Syst. Sci., 5, 389-396, 2005,

http://www.nat-hazards-earth-syst-sci.net/5/389/2005/.

Bonham-Carter, G. F., Agterberg, F. P., and Wright, D. F.: Integration of geological datasets for gold exploration in Nova Scotia, Photogramm Eng., 54, 11, 1585-1592, 1988.

Bonnard, C.: The meaning of risk assessment related to large landslides, in: "Identification and mitigation of large landslide risks in Europe: advances in risk assessment", edited by: Balkema, IMIRILAND Project., 7-12, 2004.

Cardinali, M., Reichenbach, P., Guzzetti, F., Ardizzone, F., Antonini, G., Galli, M., Cacciano, M., Castellani, M., and Salvati, P.: A geomorphological approach to estimate landslide hazard and risk in urban and rural areas in Umbria, central Italy, Nat. Hazards Earth Syst. Sci., 2, 57-72, 2002,

http://www.nat-hazards-earth-syst-sci.net/2/57/2002/.

Carrara, A., Cardinali, M., Detti, R., Guzzetti, F., Pasqui, V., and Reichenbach, P.: GIS techniques and statistical models in evaluating landslide hazard, Earth. Surf. Proc. Land., 16, 427-445, 1991.

Carrara, A., Cardinali, M., and Guzzetti, F.: Uncertainty in Assessing Landslide Hazard and Risk, ITC Journal, 2, 172-183, 1992.

Carrara, A., Cardinali, M., Guzzetti, F., and Reichenbach P.: GIS technology in mapping landside hazard. in: Geographical Information Systems in Assessing Natural Hazards, edited by: Carrara, A. and Guzzetti, F., Kluwer Acad. Publ., Dordrecht, The Netherlands, 135-176, 1995.

Corsini, A., Panizza, M., Pasuto, A., Silvano, S., Siorpaes, C., and Soldati, M.: Indagini preliminari per la definizione della pericolosità da frana nella conca di Corvara in Badia (Dolomiti), Mem. Soc. Geol. It., 53, 207-224, 1998.

Corsini, A., Marchetti, M., and Soldati, M.: Holocene slope dynamics in the area of Corvara in Badia (Dolomites, Italy): chronology and paleoclimatic significance of some landslide, Geogr. Fis. Dinam. Quat., 24 (2), 127-139, 2001.

Cruden, D. M. and Varnes, D. J.: Landslides types and processes, in:
Landslides: investigation and mitigation, edited by: Turner, A. K. and Schuster, R. L.: Transportation Research Board, Special Report 247, National Academy Press, Washington, D.C., 36-75, 1996.

Dai, F. C., Lee, C. F., and Ngai, H. H.: Landslide risk assessment and management: an overview, Eng. Geol., 64, 65-87, 2002.

DMTP (Disaster Management Training Programme): Vulnerability and Risk Assessment. Module prepared by Coburn, A. W., Sspence, R. J. S., and Pomonis, A. Cambridge Architectural Research Limited. The Oast House, Malting Lane, Cambridge, UK, 68, 1994.

EPOCH: European Programme on Climatology and Natural Hazards, Contract No. EPOC-CT-900025, 1994.

Fell, R.: Landslide risk assessment and acceptable risk, Can. Geotech. J., 31, 261-272, 1994.

Fell, R. and Hartford, D.: Landslide risk management, in: Landslide risk assessment, edited by: Cruden, D. and Fell, R., Balkema, A. A., Rotterdam, 51-109, 1997.

FEMA (Federal Emergency Management Agency): Understanding your risks: Identifying Hazards and Estimating Losses, State and Local Mitigation Planning, Washington D. C., 166, 2001.

Gamba, G.: Le tariffe a forcella nell'autotrasporto di merci per conto terzi: commento, tabelle, esempi per l'applicazione per l'applicazione pratica normative e circolari ministeriali. Adeguamento delle tariffe decorrenti dal 13 agosto 2003 per effetto del D.M. 27/7/2003, II edizione, 2002.

GETS: Geomorphology and Environmental impact assessment to Transportation Systems, Contract No. ERBFMRXCT970162, 2001.

Giacomelli, P.: Economic evaluation of risk. The case of a mountain area. Final report of ALARM project. Aracne Ed., Roma, Italy, 145, 2005.

Glade, T.: Vulnerability assessment in landslide risk analysis, Die Erde, 134, 2, 123-146, 2003.

Guzzetti, F.: Landslide fatalities and the evaluation of landslide risk in Italy, Eng. Geology, 58, 89-107, 2000.

Heinimann, H. R., Hollenstein, K., Kienholz, H., Krummenhacher, B., and Mani, P.: Methoden zur Analyse und Bewertung von Naturgefahren, Umwelt-Materialien Nr. 85, Naturgefahren, BUWAL, Bern, 248, 1998.

Heinimann, H. R.: Risikoanalyse bei gravitativen NaturgefahrenMethode, Umwelt-Materialien, 107/I, Bern, 115, 1999.

Hollenstein, K.: Reconsidering the risk assessment concept: Standardizing the impact description as a building block for vulnerability assessment, Nat. Hazards Earth Syst. Sci., 5, 301-307, 2005,

http://www.nat-hazards-earth-syst-sci.net/5/301/2005/.

IUGS: Quantitative Risk Assessment for Slopes and Landslides the State of the Art. in: IUGS Working Group on Landslides, Committee on Risk Assessment, edited by: Cruden, D. M. and Fell, R.: Landslide Risk Assessment, Balkema, Rotterdam, The Netherlands, 3-12, 1997.

Kienholz, H.: Naturgefahren-Naturrisiken im Gebirge, Schweizerische Zeitschrift fur Forstwesen, 145, 1-25, 1994.

Leone, F., Astè, J. P., and Leroi, E.: Vulnerability assessment of element exposed to mass movements: working toward a better risk perception, in: Landslides, Glissements de terrain, edited by: Senneset, K., Proceeding of VII Int. Sym. Landslides, Trondheim, Rotterdam, The Netherlands, 263-270, 1996. 
Leroi, E.: Landslides hazard-risk maps at different scales: objectives, tools and development, in: Proceeding of VII Int. Sym. Landslides, Trondheim, Rotterdam, edited by: Senneset, K.: Landslides, Glissements de terrain, The Netherlands, 35-51, 1996.

Liu, X., Yue, Z. Q., Tham, L. G., and Lee, C. F.: Empirical assessment of debris flow risk on a regional scale in Yunnan province, Southwestern China, Environ. Manage., 30 (2), 249-264, 2002.

Machina, M.: Expected Utility Theory without the independence axiom., Econometrica, 50, 277-323, 1982.

Michael-Leiba, M., Baynes, F., and Scott, G.: Quantitative landslide risk assessment of Cairns, Australia, in: Landslides in Research, edited by: Bromhead, E., Dixon, N., and Ibsen, M. L., Theory and Practice, 3 volumes, Proceedings of VIII International Symposium on Landslides, Cardiff, Wales, 26-30 June 2000, Thomas Telford, London 2, 1059-1064, 2000.

Mountain Risks: from prediction to management. EC Contract No. MRTN-CT-2006-035798, 2007.

NEWTECH: NEW TECHnologies for landslide hazard assessment and management in Europe, Contract No. ENV-CT 96-0248, 1998.

NRC (National Research Council): Risk Assessment in the Federal Government: Managing the Process, Washington D.C.: National Academy Press, 128, 1983.

NRC (National Research Council): Understanding Risk, Informing Decision in a Democratic Society, Stern, P. C. and Fineberg, H. V.(Eds), Washington D.C., National Academy Press, 249, 1996.

Panizza, M., Corsini, A., Marchetti, M., Pasuto, A., Silvano, S., and Soldati, M.: Cartographie du risque de terrain in Italie: un exemple d'une étude pilote au Tyrol du Sud. International Colloquium on "Natural risks and national development in Europe, Grand Arche de la Défense, Paris, 22-25 October 2002, 25-28, 2002.

Pearce, D.: Valuing Risks, in: Handbook of Environmental Risk Assessment and Management, edited by: Calow, P., Blackwell Science, Oxford, UK, 345-378, 1998.
Polelli, M.: Trattato di Estimo, Maggioli, Rimini, 2000.

Purchase, I. F. H.: Risk assessment. Principles and consequences, Pure Appl. Chem., 72 (6), 1051-1056, 2000.

Raetzo, H., Lateltin, O., and Tripet, J. P.: Hazard assessment in Switzerland. Codes of Practice for mass movements, B. Eng. Geol. Environ., 61, 263-268, 2002.

Schuster, R. L.: Socioeconomic significance of landslides, edited by: Turner, A. K. and Schuster R. L.: Landslides, in: Investigation and mitigation, Transportation Research Board, Special Report, 247, National Academy Press, Washington, D.C., U.S., 12-35, 1996.

Soldati, M., Corsini, A., and Pasuto, A.: Landslides and climate change in the Italian Dolomites since the Late glacial, Catena, 55, 141-161, 2004.

Starmer, C. V.: Explaining Risky Choices without Assuming Preferences, Soc. Choice Welfare, 13, 201-213, 1996.

Starmer, C. V.: The Economics of Risk, in: The Handbook of Environmental Risk Assessment, edited by: Callow, P., Blackwell Science, Oxford, UK, 319-344, 1998.

UNDRO (United Nations Disaster Relief Coordinator): Natural Disasters and Vulnerability Analysis in Report of Expert Group Meeting (9-12 July 1979), UNDRO, Geneva, 1979.

Varian, H. R.: Intermediate Microeconomics. A Modern Approach (Second Edition), W. W. Norton and Company, Inc., New YorkLondon, 1990.

Wu, T. H., Tang, W. H., and Einstein, H. H.: Landslide hazard and risk assessment, in: Transportation Research Board Special Report, edited by: Turner, A. K. and Schuster, R. L.: Landslides, Investigation and Mitigation, 247, National Academy Press, Washington D.C., USA, 106-118, 1996. 